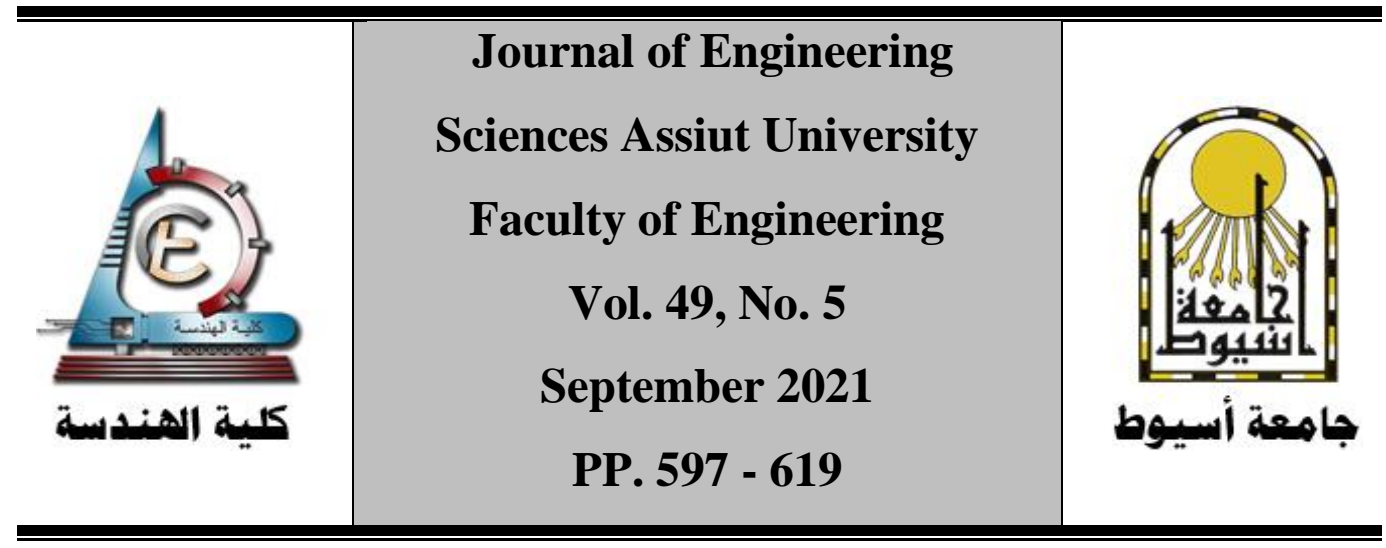

\title{
Sponge-Mediated Moringa Oleifera Seeds as A Natural Coagulant in Surface Water Treatment
}

\author{
Ahmed Farghaly"1 ${ }^{*}$ Esraa M. Abd El-Hamied², Ali A. M. Gad ${ }^{1}$ \\ ${ }^{1}$ Civil Engineering Department, Assiut University, 71515, Assiut, Egypt \\ A.m.farghaly@aun.edu.eg \\ ${ }^{1}$ Civil Engineering Department, Assiut University, 71515, Assiut, Egypt \\ aligad64@yahoo.com \\ ${ }^{2}$ Company of Drinking Water and Wastewater, 82511, Sohag, Egypt \\ esraamouhamed575@gmail.com
}

\begin{abstract}
Moringa Oleifera seeds (MOS) coagulant has been used as a coagulation agent in water purification. In developing countries, usage of MOS addresses many advantages namely eco-friendly, biodegradable, available and cost-effective coagulant, resulting in a powerful alternative to chemical coagulants. This research revealed the positive effect of MOS with the aid of sponge at different operational conditions and showed a great influence in the purification efficiency without any observed clogging of sponge pores or bad smell emission. Supplementation of the sponge improved the purification efficiency in terms of turbidity and $\mathrm{UV}_{254}$ substances removal from $96 \%$ and $72 \%$ to be $99 \%$ and $93 \%$, respectively with reduced MOS coagulant from 50 to $15 \cdot \mathrm{mg} / \mathrm{L}$, respectively. Finally, response surface methodology (RSM) has been employed to get the optimum operational conditions for a residual turbidity valueless than1.0 NTU, which occurred at MOS dose of $250 \mathrm{mg} / \mathrm{L}$ and $\mathrm{pH}$ value of 6.15 after 12 minutes of treatment.
\end{abstract}

Keywords: Natural coagulant, Moringa Oleifera, coagulation, oil-extraction, Response Surface Methodology (RSM). 


\section{Introduction}

Nile River is considered the main source of drinking water in Egypt; however, it faces a great risk of ever-pollution. The conventional sources of Nile pollution include improper discharge of industrial wastewater, agricultural wastewater containing pesticides and chemical fertilizers residues, or domestic pollution. Thus, it is of a prime urgency to find a clean low-cost treatment approach to protect the developing countries' populations.

One of the most conventional effective treatment methods is coagulation/flocculation using several materials with different chemical characteristics focusing on color and turbidity removal. These coagulants are classified into inorganic, synthetic organic polymers, and natural coagulants. The two most commonly used coagulants are alum and iron (III) salts which prove excellent performance and are actually applied worldwide [1]. However, recent studies have pointed out numerous drawbacks of using them viz. Alzheimer disease which associated with aluminum residues in treated water as well as production of large sludge volumes [2]. In addition, the use of alum and iron salts is inappropriate in some developing countries because of their high capital and sludge disposal costs along with low availability in markets [3]. Instead, previous studies have focused on the introduction of natural coagulants either used as they are or extracted from microorganisms, animals or plants [4]. Although their use in water treatment is not recent, the literature suffers from lack of knowledge on their mechanism performance based on the interaction between different key parameters. Recently, a great interest in the use of natural coagulants has been grown thanks to their biodegradability, handling safety, and cost efficiency [5], [6].

Among the promising natural coagulant plants, Moringa Oleifera seeds (MOS) have been shown to be one of the effective primary coagulants for water treatment. MO is a tropical plant belonging to the family of Moringaceae. Up to fourteen different species have so far been identified, all of them possess varying degrees of coagulation activity [7]. MO tree grows quickly at low altitudes in the whole tropical belt including arid zones [8]-[10]. It is generally known in developing countries as a vegetable oil source. However in Sudan for example, it is traditionally used in water purification [11], [12].

Idris et al.[13] focused on MOS characteristics and their possible applications. MOS are a source of protein, calcium, iron, carotenoids, and phytochemicals and could be utilized for several usages. MOS contain 30\% - 40\% (w/w) oil, which represents a valuable resource for industrial, food, and renewable energy applications. They would be used in medicine purposes, cosmetics industry, food supplements and enhancements, and water purification as shown in Fig. 1. 


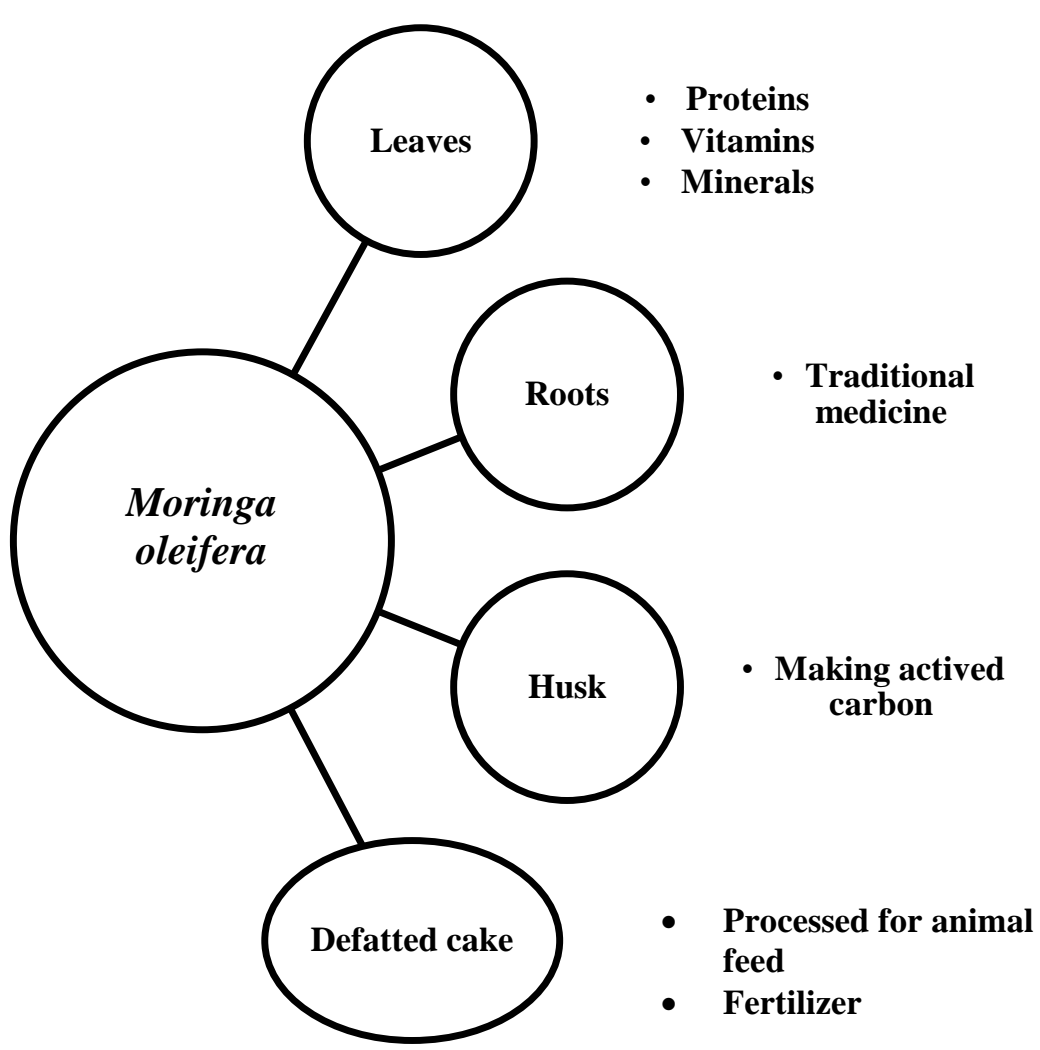

Figure 1. Contents of Moringa Oleifera and their applications after its harvest

According to Ndabigengesere and Narasiah [2], MOS may be an alternative coagulant replacing alum salts in water treatment. MOS coagulant has the same ability in the range of temperature 20 to $40{ }^{\circ} \mathrm{C}$ either for surface water treatment or industrial effluents, which affords an add-value for its usage [14], [15]. Their efficiency is based on the entire cationic protein of a high molecular weight which destabilizes particles in polluted water. However, the oil content increases the organic matter concentration and avoids the storage of treated water after $24 \mathrm{~h}$. The organic content also can react with chlorine during chlorination to form halogenated disinfection by products such as trihalomethanes (THMs) [16], which are classified as potential carcinogenic substances and associated with health and aesthetic problems for consumers. Instead, extraction of oil using hexane or ethanol with saline solutions $(\mathrm{NaCl}$, $\mathrm{KCl}$, etc.) may achieve excellent coagulation activity with a slight effect on THMs formation during the treatment [16], [17]. The resultant MOS coagulant is perfectly able to remove color, turbidity, and $\mathrm{UV}_{254}$ substances [18]. MOS coagulant performance refers to the positive interaction between solvent and coagulant protein [19]-[21]. In addition, salting-in mechanism of MOS 
coagulant increases protein dissociations, leading to increasing protein solubility as the salt ionic strength increases.

Sapana et al. [22] studied the effect of MOS coagulant at doses of 50 to 150 $\mathrm{mg} / \mathrm{L}$ for ground water treatment with initial turbidity of $12.4 \mathrm{NTU}$. They observed that the turbidity decreased concurrently with increasing MOS dose to be $3.1 \mathrm{NTU}$, achieving $75 \%$ turbidity removal at dose of $150 \mathrm{mg} / \mathrm{L}$ with final $\mathrm{pH}$ value between 7 - 7.5. They reported an increase of $\mathrm{pH}$ with increasing MOS doses. Baptista et al. [18] studied MOS coagulant to reduce the contamination of surface water with initial turbidity of 75 NTU without increasing the organic material in the treated effluent. A dose of $13.78 \mathrm{mg} / \mathrm{L}$ at $\mathrm{pH}$ of 7.98 achieved a removal efficiency of color (89.15\%), turbidity (88.75\%), and compounds with $\mathrm{UV}_{254}$ substances (75.93\%) with low residual dissolved organic carbon concentration. Beltrán-Heredia et al. [15] compared the ability of two natural coagulants for Alizarin Violet 3R (anthraquinonic dye) removal, (ACQUAPOL C-1 and MOS coagulant). Eighty percent of removal has been done using $100 \mathrm{mg} / \mathrm{L}$ of MOS coagulant compared with 400 $\mathrm{mg} / \mathrm{L}$ in the case of ACQUAPOL C-1. They also concluded an inverse relationship between $\mathrm{pH}$ and MOS efficiency. The entire protein in MOS has a cationic nature that may imply enhancement of the coagulant activity at low $\mathrm{pH}$. This result agreed with Ghebremichael et al. [23] findings who studied the optimum $\mathrm{pH}$ from 5 to 9 . The coagulation performance started to decline beyond $\mathrm{pH}$ of 7 .

From the point of economy and to find a low-cost purification way, using of sponge was proposed to be supplemented to the treatment approach. Sponge has a void ratio of more than $90 \%$, which provides dual benefits: (1) prolonging the contact time between MOS coagulant and pollutants, (2) acting as a natural filtration system. In addition, sponge is characterized by long life span and very light weight that does not represent an excessive load to the treatment basin. The sponge were successfully used in wastewater treatment systems based on the retained microbial communities inside [24], [25]. To best of our knowledge, sponge was not applied in water treatment systems with MOS coagulant. Therefore, this study aims to investigate the efficiency of MOS coagulant at different coagulant doses, $\mathrm{pH}$ values, and coagulation times with/without sponge supplementation. The response surface methodology (RSM) was applied using Minitab ${ }^{\circledR} 17.0$ to find out the optimum combination of those parameters during the coagulation process with respect to the lowest value of residual turbidity. This demonstrates the benefits of the approach based on RSM in achieving good predictions while minimizing the number of the required experiments. 


\section{Materials and Samples Preparation}

\subsection{Characterization of raw water and sponge}

Raw surface water used in assays was collected from Al-Faroukeya canal, Sohag, Egypt $\left(26^{\circ} 33^{\prime} \mathrm{N} 31^{\circ} 42^{\prime} \mathrm{E}\right)$ from two different locations. MOS were brought from Cairo National Research Center, Egypt. Parameters of color and compounds with $\mathrm{UV}_{254}$ absorbance were measured using a Spectrophotometer Evolution $300 \mathrm{BB}$. Turbidity was estimated by turbidimeter 2100Q HACH, while $\mathrm{pH}$ values were measured by $\mathrm{pH}$ meter HANNA-HI 98128, and the color of the samples were admitted visually. Samples collected from point 1 were used for experiments without sponges while those from point 2 were used for experiments with sponges.

Polyurethane sponge with pore size of $0.63 \mathrm{~mm}$ and void ratio of more than $90 \%$ was used. The dimensions of the used polyurethane sponge (cylindrical shape) were about 35 height $\times 22 \mathrm{~mm}$ diameter. The surface area of the used sponge was $256 \mathrm{~m}^{2} / \mathrm{m}^{3}$ and density of $30 \mathrm{~kg} / \mathrm{m}^{3}$.

\subsection{MOS coagulant solution preparation}

Dried MOS were shelled, and their kernels were ground to a fine powder. MOS underwent an oil-extraction process with ethanol as a solvent, as described by Sánchez-Martín et al. [26]. According to Garcia-Fayos et al. [27], using ethanol achieved the maximum coagulant efficiency for low coagulant concentration doses. MOS coagulant was prepared in the day of testing by the addition of 1.0 $\mathrm{gm}$ of defatted seeds after the extraction process to $0.1 \mathrm{~L}$ of saline solution $(\mathrm{NaCl} 1 \mathrm{M})$ to produce MOS coagulant solution with a concentration of $10 \cdot 0$ $\mathrm{mg} / \mathrm{L}$. This was followed by shaking with a shaker for 30 minutes as described by previous research [5]. After shaking the solution, it was filtered using filter papers with pore size of $0.45 \mu \mathrm{m}$ and added to the raw water with the required amount to produce a certain concentration. Fig. 2 shows the experimental setup for studying the effect of MOS coagulant with/without sponges supplementation at different operating conditions on water purification.

\subsection{Coagulation and flocculation experiments}

\subsubsection{MOS performance with/without sponges}

Experimental tests were conducted using jar test apparatus with raw water from point 1 without sponges, and from point 2 with sponges supplementation at constant $\mathrm{pH}$ of 7.5 with five different $\operatorname{MOS}$ doses $(15 \cdot, 25 \cdot, 35 \cdot, 50 \cdot$ and 60 . $\mathrm{mg} / \mathrm{L}$ ). The experiments ran at three phases: (1) with speed stirring at $200 \mathrm{rpm}$ for 1.0 minute, (2) low speed stirring of $32 \mathrm{rpm}$ for 30 minutes, and (3) settling for $24 \mathrm{~h}$ into beakers $(1 \mathrm{~L})$. After that, aliquots were taken just $10 \mathrm{~cm}$ 
602

JES, Assiut University, Faculty of Engineering, Vol. 49, No. 5, Sept. 2021, pp. 597 - 619

underneath the water surface to analyze color, turbidity, and compounds with adsorption of $U^{254}$. For tests with sponge's supplementation, fifty pieces of sponge with dimensions $4 \times 4 \times 2 \mathrm{~cm}$ were soaked firstly in MOS coagulant solution for 45 minutes to ensure full saturation. Subsequently, the experiments were started using the jar test apparatus with the same phases. For MOS tests with sponges, pieces of sponge were supplemented to the beakers equally. After experiments, random sponge pieces were collected and used for SEM analysis to compare their internal morphology with the initial status. After that, $\mathrm{pH}$ was varied at 4, 6, and 8 and experiments were repeated at the optimum obtained MOS dose with/without sponges supplementation using $0.1 \mathrm{HCl}$ or $0.1 \mathrm{NaOH}$ to adjust $\mathrm{pH}$ to the required.

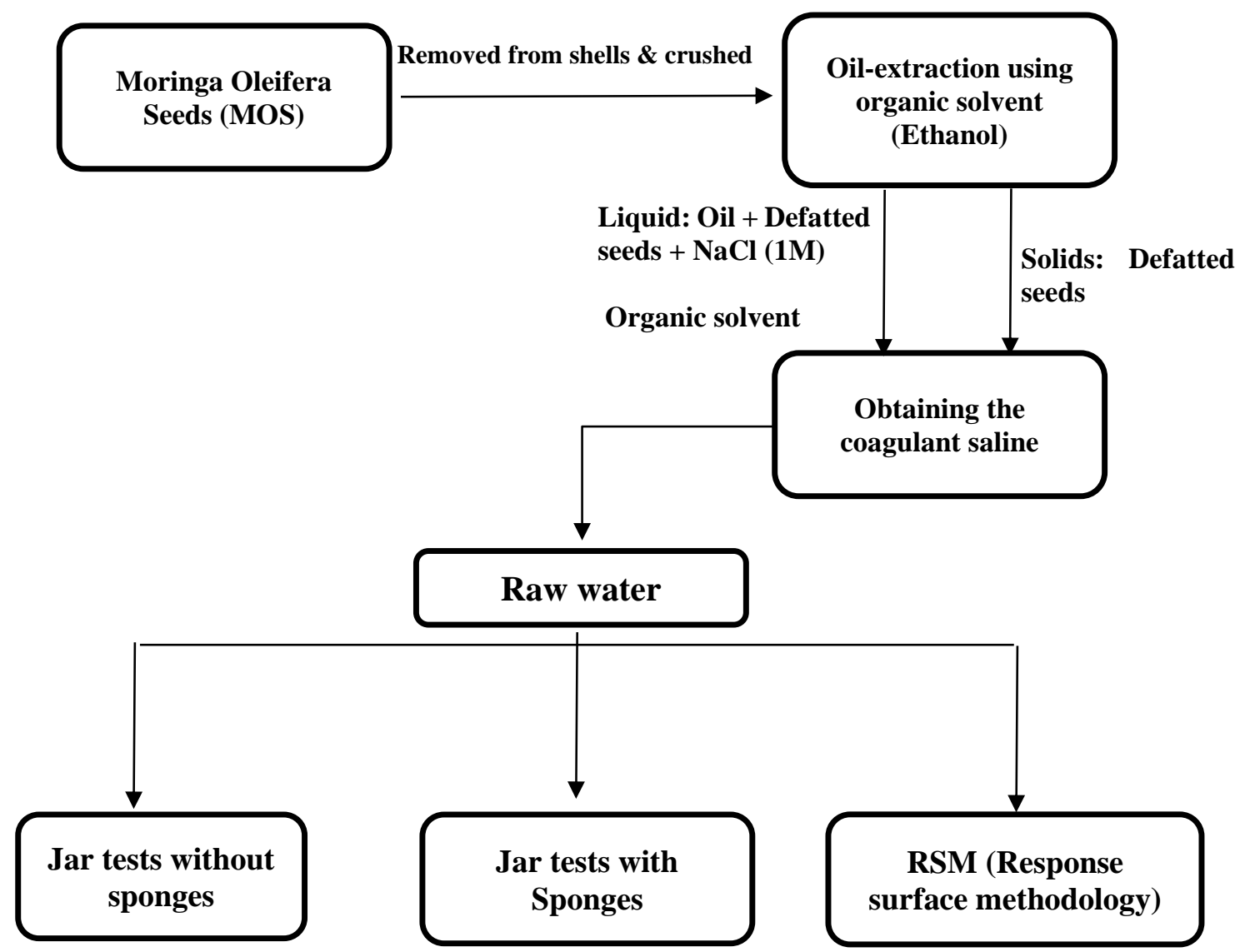

Figure 2. The flow chart for studying the effect of MOS coagulant on surface water purification with/without sponges supplementation at different operating conditions. 


\section{Results and analysis}

\subsection{Effect of MOS coagulant dose with/without sponge supplementation}

The characteristics of the used raw water from point 1 and point 2 on Al-Faroukeya canal are given in Table 1. The concerned parameters were evaluated before and after assays to verify the influence of MOS coagulant with/without sponge supplementation on high turbid surface water treatment processes.

Table 1. Raw surface water characterization

\begin{tabular}{lll}
\hline \multirow{2}{*}{ Parameter } & \multicolumn{2}{c}{ Mean values } \\
\cline { 2 - 3 } & \multicolumn{1}{c}{$\begin{array}{c}\text { Point 1 (for experiments } \\
\text { without sponges) }\end{array}$} & $\begin{array}{c}\text { Point 2 (for } \\
\text { experiments with } \\
\text { sponges) }\end{array}$ \\
\hline Turbidity (NTU) & 60 & 107 \\
pH values & 7.5 & 7.5 \\
UV $_{254}$ absorbance & 0.854 & 0.870 \\
Color (Fig. 3) & Light brown & Moderate brown \\
\hline
\end{tabular}

Experimental tests were conducted to compare the different dosages of MOS coagulant and its effect on water treatment with/without sponge supplementation. The initial brown color of raw water at the two points was completely removed after treatment using MOS coagulant whatever the used dose and sponge supplementation as shown in Fig. 3. On the other hand, it was observed that MOS coagulant showed a decrease in the turbidity to 2.47 NTU and $\mathrm{UV}_{254}$ absorbance to 0.245 without using sponge at a dose of $50 \cdot \mathrm{mg} / \mathrm{L}$ as given in Table 3. These values correspond to a high turbidity removal of $96 \%$ and $\mathrm{UV}_{254}$ absorbance reduction of $72 \%$. However, the turbidity still does not meet the Egyptian standards regulations for drinking water (1.0 NTU). The high turbidity removal was based on the charge neutralization of cationic protein of MOS coagulant and anionic natural organic matters (NOM) through electrostatic interactions. The matter which resulted in a formation of particle collision and neutralization and enmeshment of suspended particles that formed flocs [13]. In addition, the extraction of oil increased the coagulant efficiency due to inhibiting the formation of film coating that interferes with suspended solids and reduces floc formation.

What is more interesting, the sponge supplementation proved more higher efficiency. The turbidity was reduced from 107 NTU to 1.4 NTU achieving 99\% treatment efficiency and $\mathrm{UV}_{254}$ absorbance reduction of $93 \%$ at just 15 . $\mathrm{mg} / \mathrm{L}$ of MOS coagulant, confirming its economic benefit. The reason behind this result based on the high percent of voids in sponge (microfilter) that prolonged the contact time between MOS coagulant and NOM, resulting in higher performance. Thus, supplementation of sponge to MOS coagulant 
604

resulted in a great effect of enhancing the coagulation process without any clogging of the sponge pores. Figs. 4 and 5 present respectively turbidity and $\mathrm{UV}_{254}$ absorbance reduction (\%) after experiments at different MOS coagulant doses with/without sponges. The obtained results were confirmed using scanning electron microscopy (SEM) that show the retained flocs inside the sponges' voids as shown in Fig. 6, while other flocs were clearly precipitated at the bottom of the beakers as shown in Fig. 7.

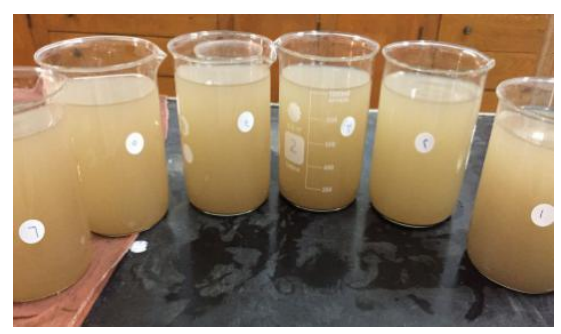

(1)

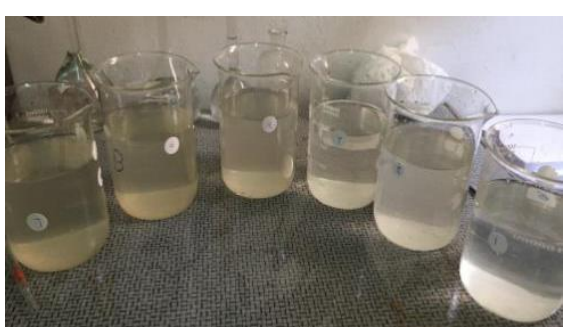

(2)

Case (a). Water treatment without sponge supplementation (observable color removal with all doses).
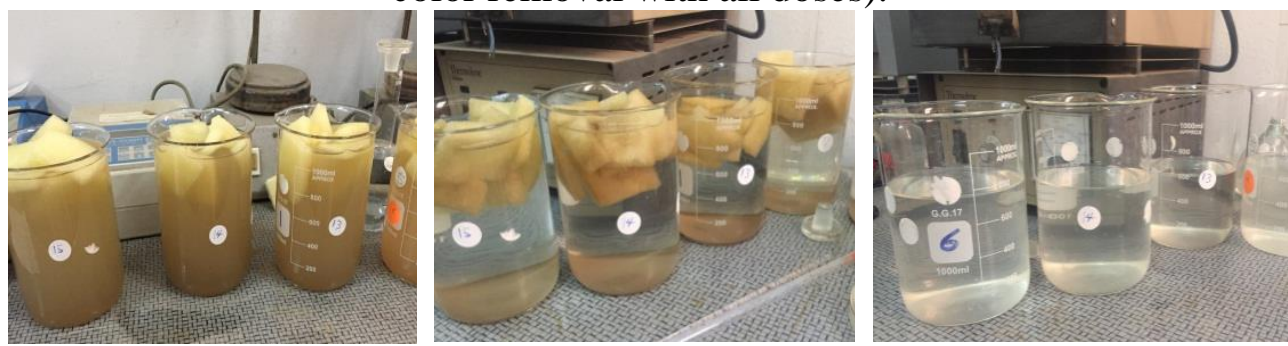

Case (b). Water treatment with sponge supplementation (almost complete color removal with all doses).

Figure 3. Color removal after water treatment experiments in all cases without (a)/with (b) sponge supplementation. Images (1 and 3): before treatment, (2, 4 and 5): after treatment. 


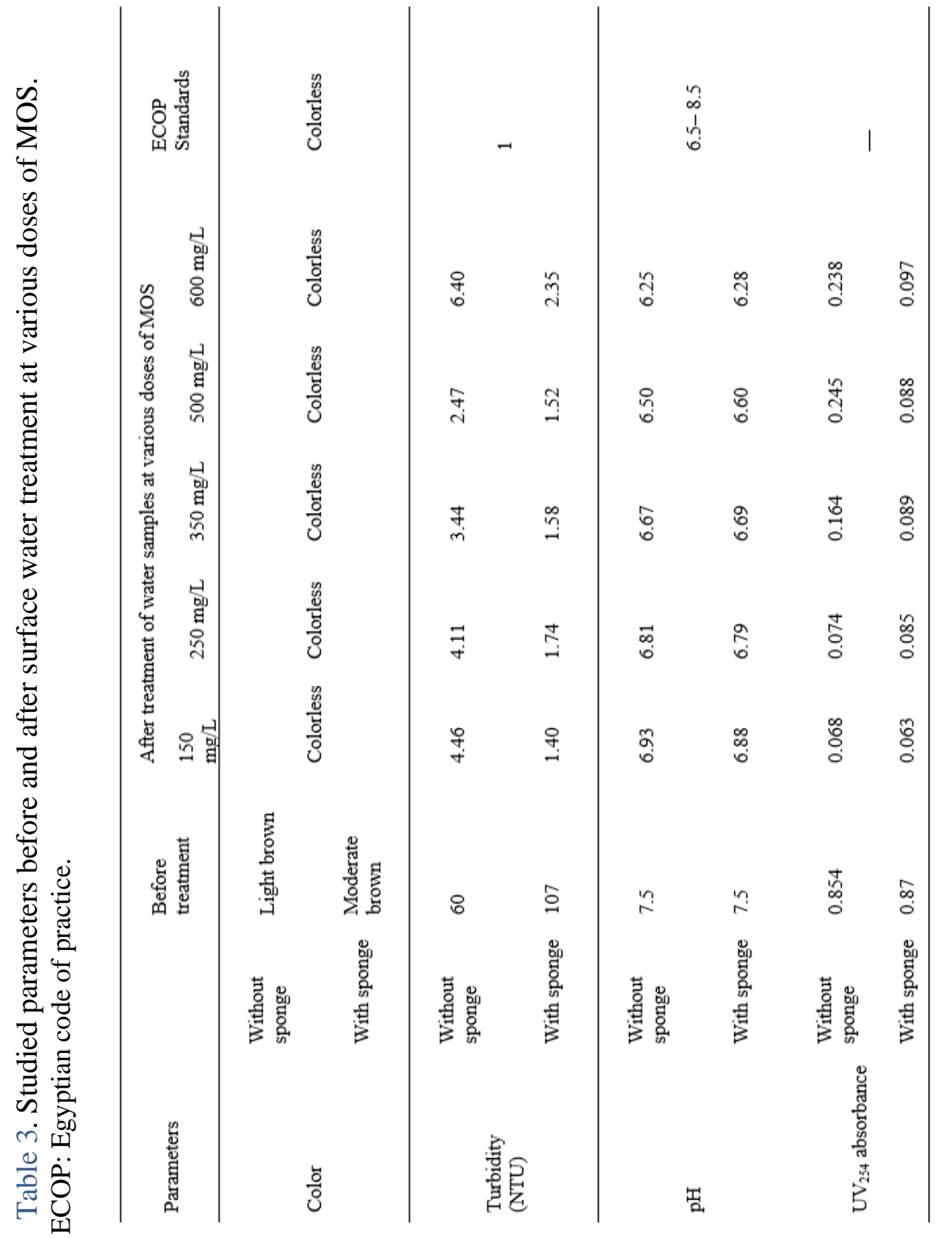


606

JES, Assiut University, Faculty of Engineering, Vol. 49, No. 5, Sept. 2021, pp. $597-619$

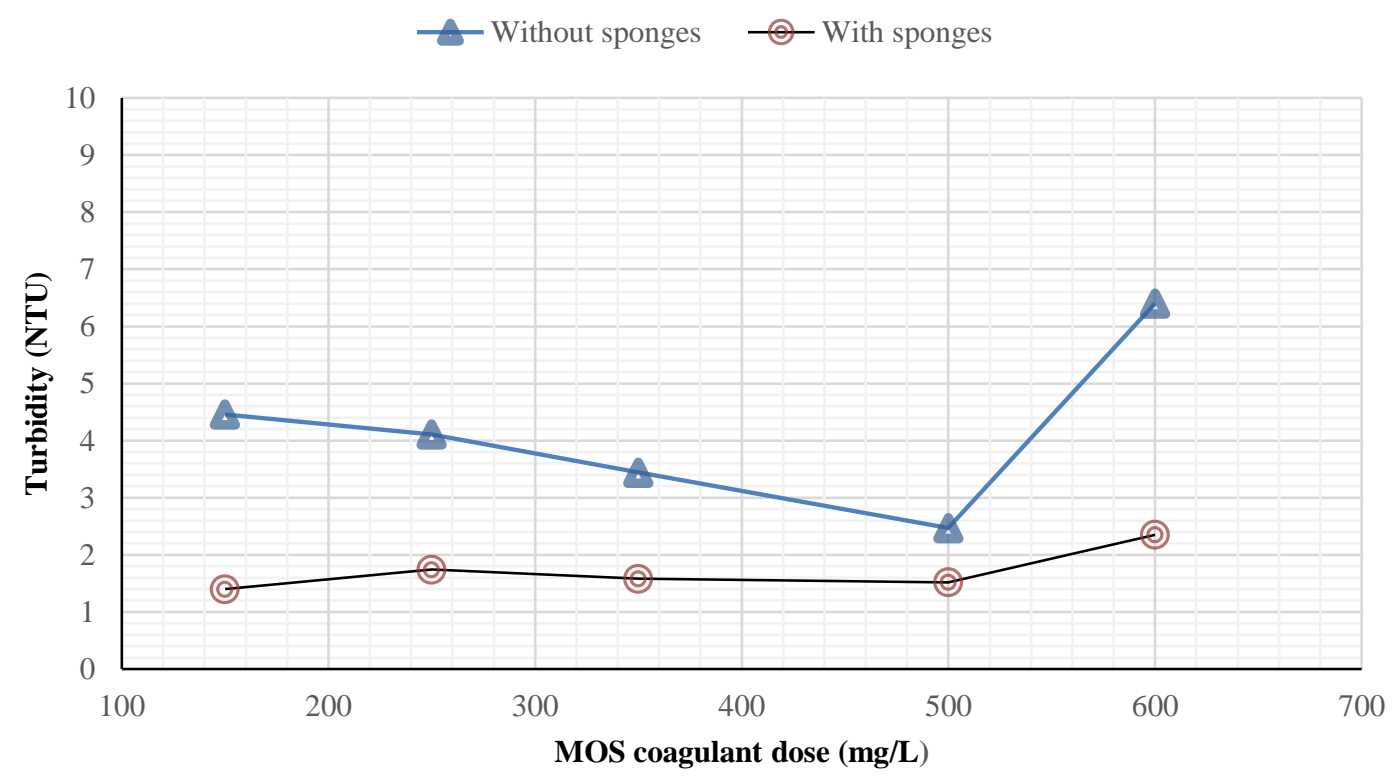

Figure 4. Turbidity values after experiments with/without sponge supplementation at different MOS coagulant doses (The initial turbidities were 60 and 107 NTU for the cases of without/with sponges, respectively).

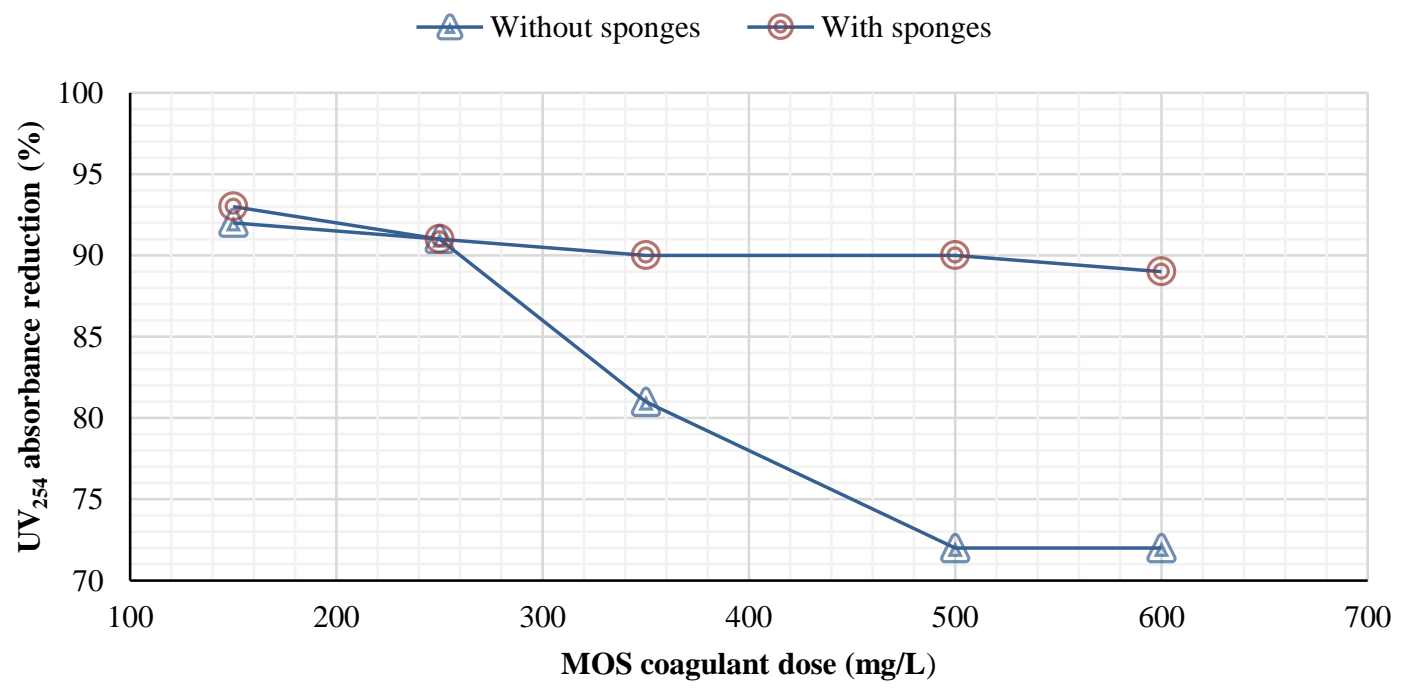

Figure 5. $\mathrm{UV}_{254}$ absorbance reduction after experiments with/without sponge supplementation at different MOS coagulant doses (The initial $\mathrm{UV}_{254}$ absorbance reduction was 0.854 and 0.870 for the cases of without/with sponges, respectively). 


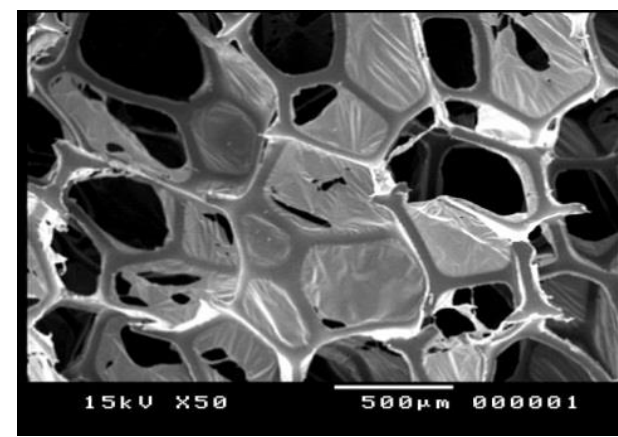

(a)

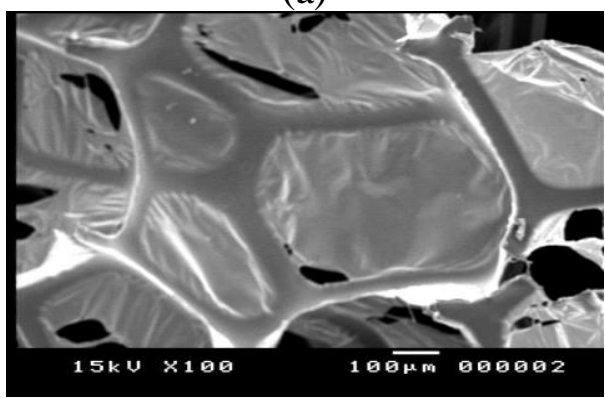

(b)

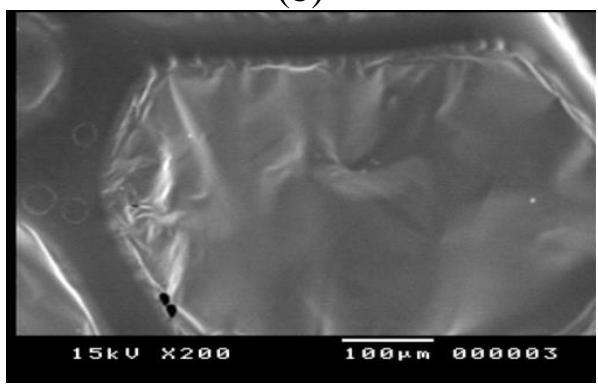

(c)

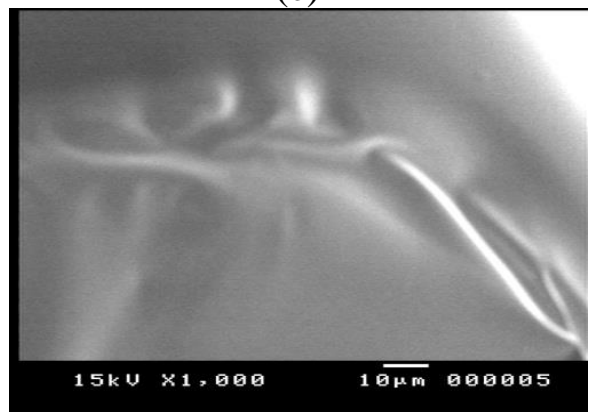

(d)

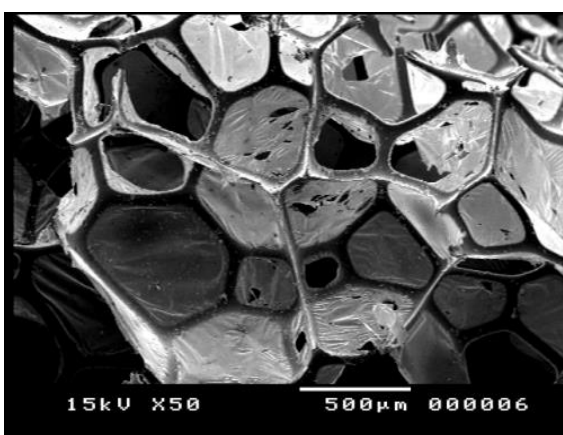

(e)

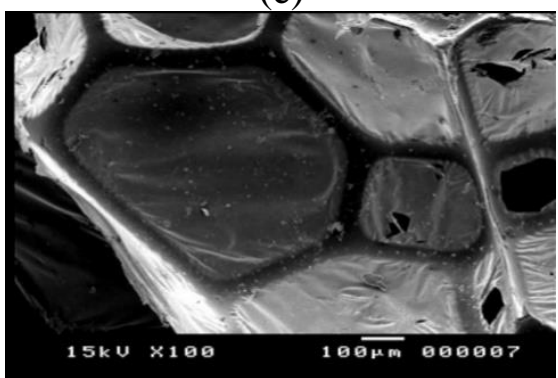

(f)

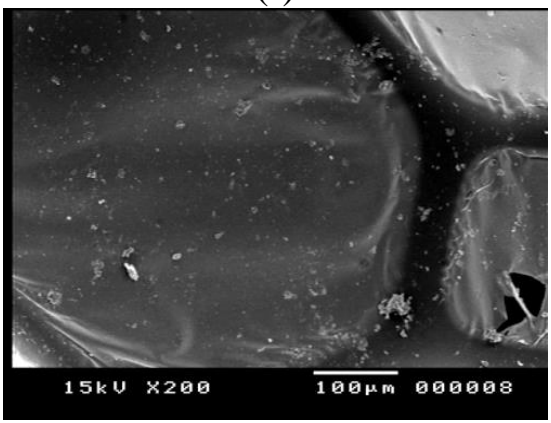

(g)

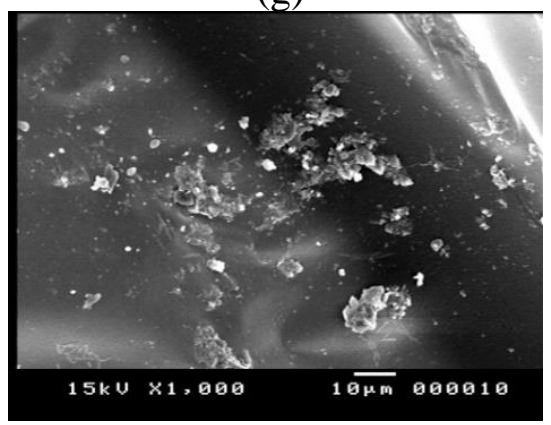

(h)

Figure 6. SEM images of sponges before $(a-d)$ and after experiments $(e-h)$ at different scales. 

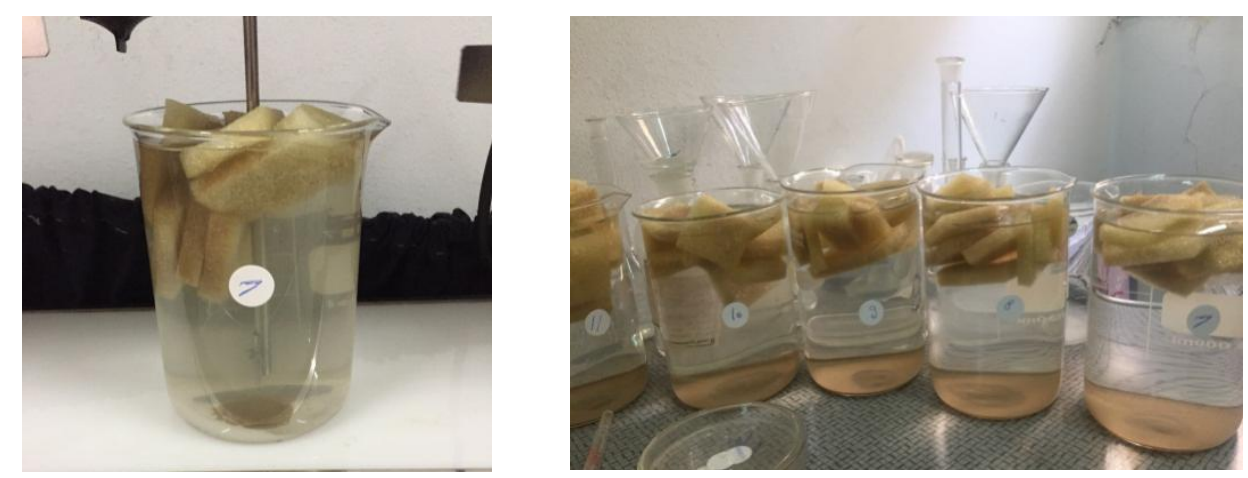

Figure 7. Flocs clearly precipitated at the bottom of beakers after treatment with sponge supplementation.

\subsection{Effect of $\mathrm{pH}$ value at the optimum MOS coagulant dose}

After determining the optimum MOS coagulant doses without and with sponge supplementation at 500 and $150 \mathrm{mg} / \mathrm{L}$, respectively, $\mathrm{pH}$ values of 4,6 and 8 were studied. The initial turbidity andUV $V_{254}$ absorbance values were 107 NTU and $60 \mathrm{NTU}$, and 0.87 and 0.854 for the cases of with/without sponge supplementation, respectively. It was observed that the best turbidity and $\mathrm{UV}_{254}$ absorbance reduction were at $\mathrm{pH}=8$ as shown in Figs. 8 and 9, respectively. Particularly, the turbidity and $\mathrm{UV}_{254}$ absorbance removal efficiency were $97 \%$ and $70 \%$ without sponge supplementation, which augmented to $99 \%$ and $88 \%$ with sponge supplementation, respectively. This result agreed with G.S. Madrona et al. [28], Okuda et al. [29] and Ndabigengesere and Narasiah's [2] observations who obtained the best removal efficiencies at $\mathrm{pH}$ value of 8 using raw water of $35 \mathrm{NTU}$ and 105 NTU, respectively. Again, the results ensures the positive efficiency of sponge supplementation whatever the $\mathrm{pH}$ value as shown in Fig. 10 and with an optimum $\mathrm{pH}$ value within the range of Egyptian standards and WHO (6-8) [22]. 


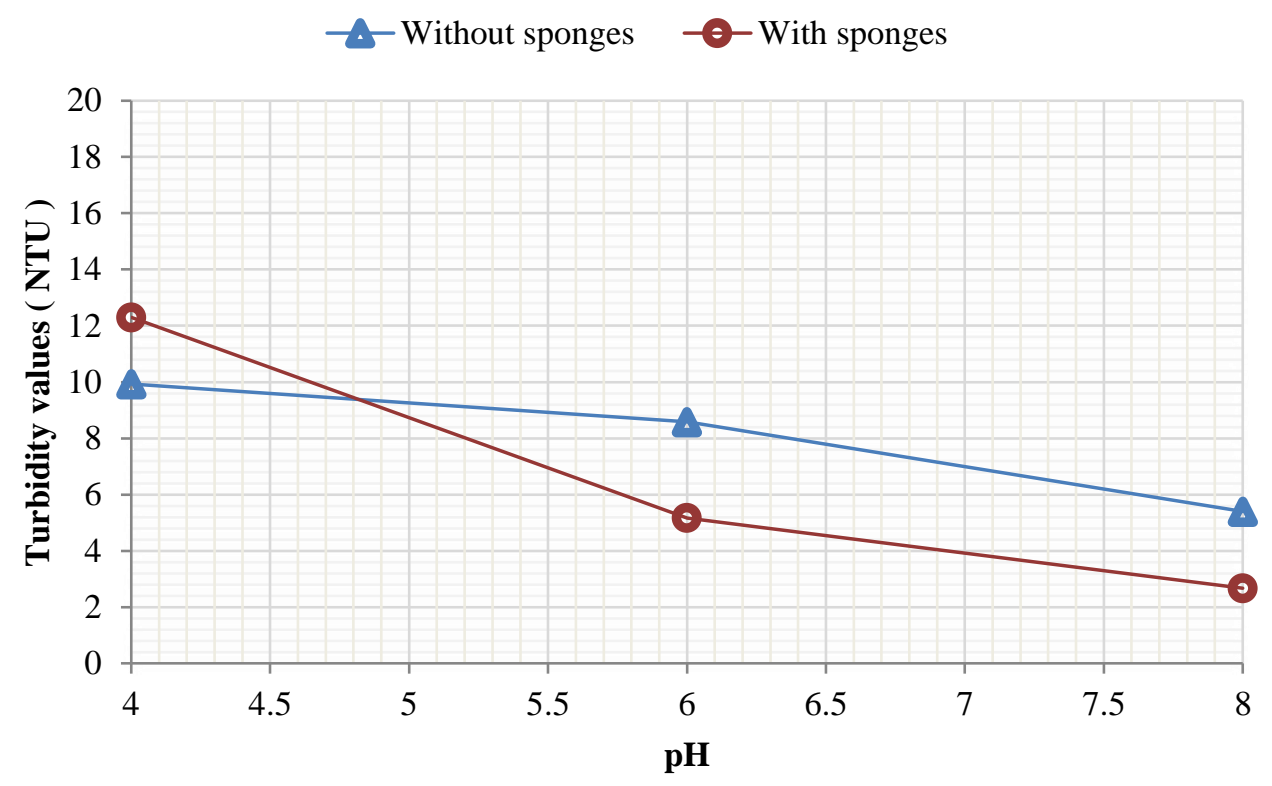

Figure 8 . Turbidity values of the treated water with/without sponge supplementation at different $\mathrm{pH}$ values.

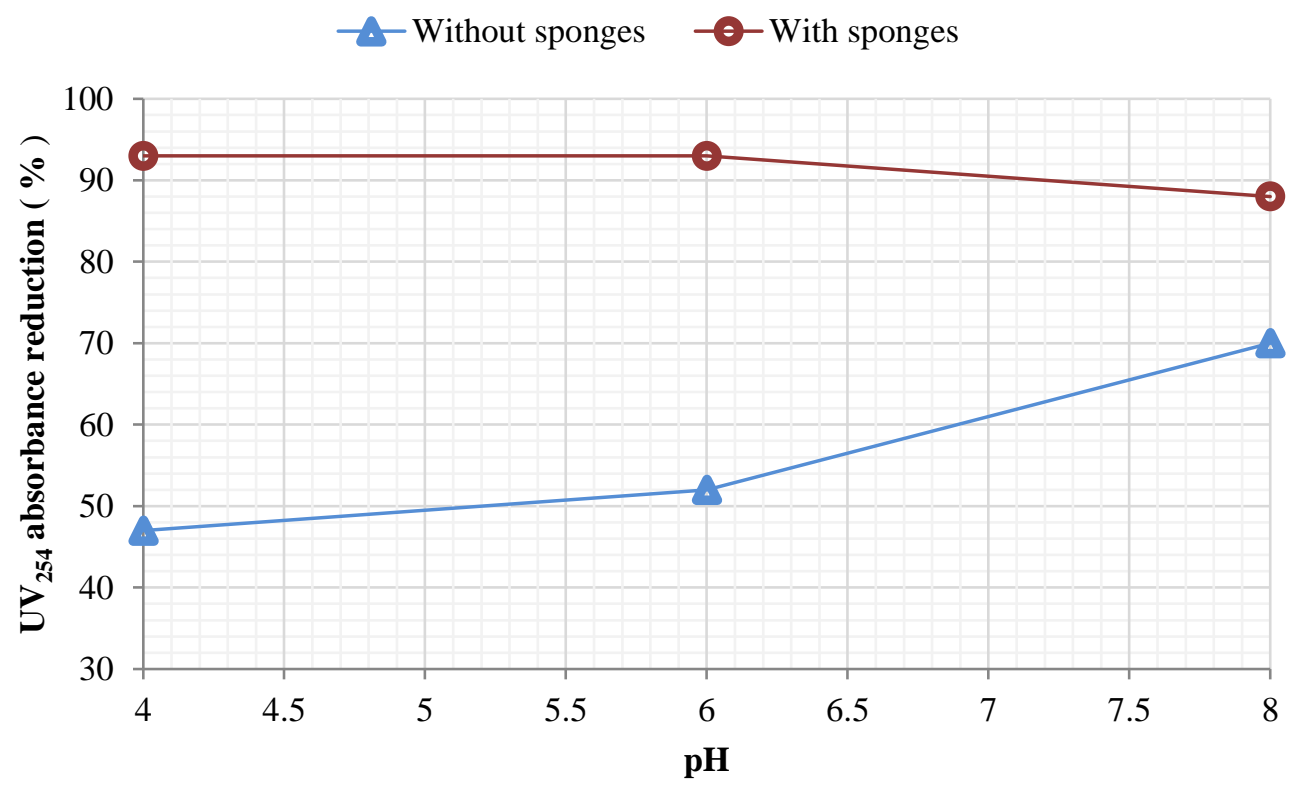

Figure 9. $\mathrm{UV}_{254}$ absorbance reduction of the treated water with/without sponge supplementation at different $\mathrm{pH}$ values. 
610

JES, Assiut University, Faculty of Engineering, Vol. 49, No. 5, Sept. 2021, pp. 597 - 619

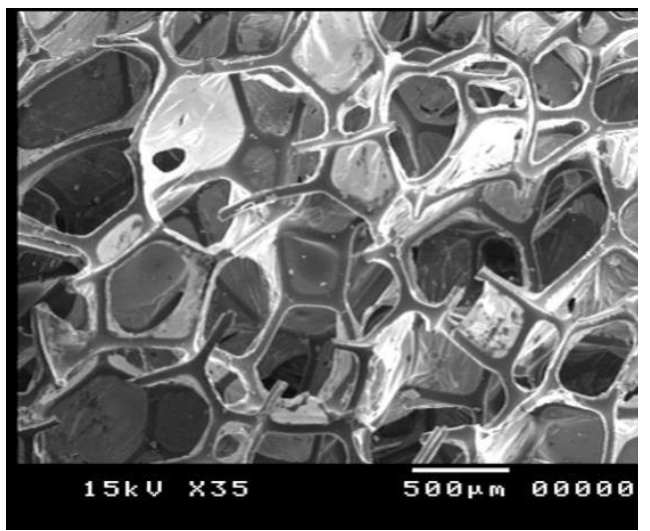

SEM image of sponge at $\mathrm{pH}=8$

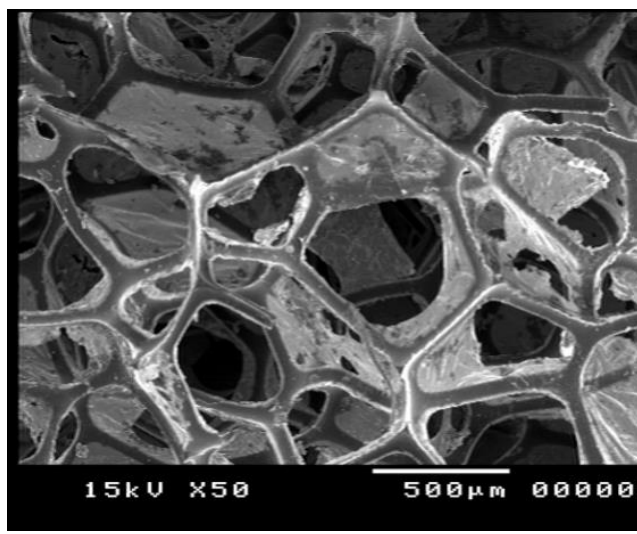

SEM image of sponge at $\mathrm{pH}=6$

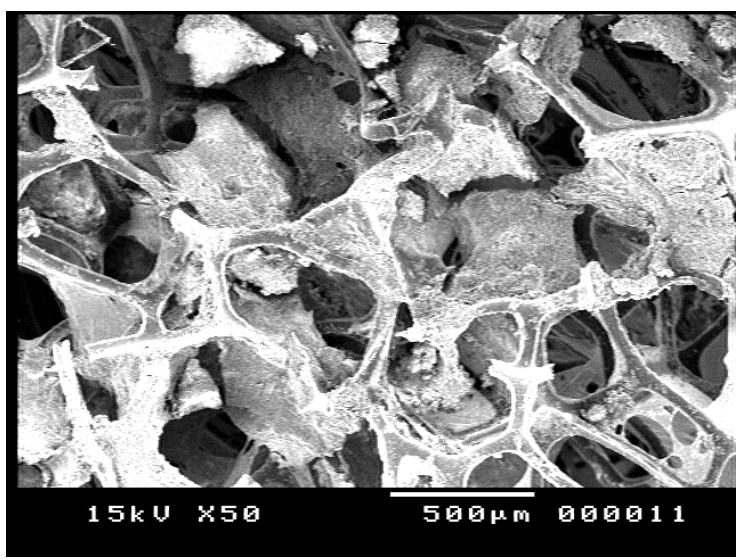

SEM image of sponge at $\mathrm{pH}=4$

Figure 10. SEM images of sponges after treatment at different $\mathrm{pH}$ values.

\section{Continuous mode: Response surface methodology (RSM)}

RSM was used to investigate the optimum conditions of using MOS coagulant supplemented with sponge at different doses, $\mathrm{pH}$ values, and contact time for operating a treatment system in continuous mode applications. The principle of RSM was described by Khuri and Cornell (1996) [30]. To achieve adequate and reliable measurements of the responses of interest, the design of experiment is necessary. Normally, the relationship between the response (turbidity) and the independent variables (coagulant dose, $\mathrm{pH}$, and time) in coagulation-flocculation process would not be well modeled by a linear function or a first order model. A model that incorporates curvature is usually required to approximate the response in the region close to optimum. A 
Behnken box design, which is a very efficient design tool, was selected for use in the present study. The Behnken box design of this work is presented in Table 2. To determine if a relationship exists between the independent factors and the investigated response parameter, the collected data was analyzed statistically using regression analyses. The response can be expressed as second-order polynomial equations, according to Eq. (1):

$$
\begin{aligned}
Y=f(x)=\beta o & +\beta_{1} X_{1}+\beta_{2} X_{2}+\beta_{3} X_{3}+\beta_{11} X_{1}^{2}+\beta_{22} X_{2}^{2}+\beta_{33} X_{3}^{2} \\
& +\beta_{12} X_{1} X_{2}+\beta_{13} X_{1} X_{3}+\beta_{23} X_{2} X_{3}
\end{aligned}
$$

Where $\mathrm{Y}$ is the predicted response (turbidity); while $\mathrm{pH}\left(\mathrm{X}_{1}\right)$, MOS dose $\left(\mathrm{X}_{2}\right)$ and time $\left(\mathrm{X}_{3}\right)$ are the factors which influence the predicted response $\mathrm{Y} ; \beta \mathrm{o}$ is the constant coefficient; $\beta_{1}, \beta_{2}$ and $\beta_{3}$ are the coefficients of linear, interaction, and quadratic term, respectively. The coefficient parameters of the secondorder models were estimated using a multiple linear regression analysis employing Minitab $^{\circledR}$ 17.0.

Table 2. The experimental design according to RSM.

\begin{tabular}{cccc}
\hline Run no. & $\mathrm{pH}(\mathrm{X} 1)$ & Dose $(\mathrm{X} 2)(\mathrm{mg} / \mathrm{L})$ & Time $(\mathrm{X} 3)(\mathrm{minutes})$ \\
\hline 1 & 6 & 50 & 25 \\
2 & 7.5 & 250 & 10 \\
3 & 6 & 250 & 25 \\
4 & 9 & 250 & 25 \\
5 & 7.5 & 150 & 25 \\
6 & 9 & 50 & 25 \\
7 & 7.5 & 150 & 25 \\
8 & 9 & 150 & 10 \\
9 & 6 & 150 & 10 \\
10 & 9 & 150 & 40 \\
11 & 7.5 & 50 & 40 \\
12 & 7.5 & 150 & 25 \\
13 & 6 & 150 & 40 \\
14 & 7.5 & 250 & 40 \\
15 & 7.5 & 50 & 10 \\
\hline
\end{tabular}

\subsection{Response surface methodology (RSM): fitting the models}

The Behnken Box (Table 2) allowed the development of mathematical equations where each response $\mathrm{Y}=f(x)$ was assessed as a function of $\mathrm{pH}$ value, MOS coagulant dose, and time. It was further calculated as the sum of a constant, three linear effects, three quadratic effects and one interaction effect according to Eq. (1). The results of the fitted models for turbidity are given in 
Eq. (2) and the experimental and predicted turbidity values according to RSM are shown in Table 4, with an initial experimental turbidity of 110 NTU.

Turbidity $(\mathrm{NTU})=-7.7+3.44 \mathrm{pH}-1.097$ Dose +0.802 Time $-0.329 \mathrm{pH}^{2}$

$$
\begin{aligned}
& +0.01513 \text { Dose }^{2}-0.01006 \text { Time }^{2}+0.0893 \mathrm{pH}^{*} \text { Dose } \\
& \text { - 0.0090 } \mathrm{pH}^{*} \text { Time - 0.01167 Dose*Time }
\end{aligned}
$$

Table 4. The experimental and predicted turbidity values according to RS

\begin{tabular}{cccccc}
\hline Run no. & $\mathrm{pH}(\mathrm{X} 1)$ & $\begin{array}{c}\text { Dose }(\mathrm{X} 2) \\
(\mathrm{mg} / \mathrm{L})\end{array}$ & $\begin{array}{c}\text { Time }(\mathrm{X} 3) \\
(\text { minutes })\end{array}$ & $\begin{array}{c}\text { Measured } \\
\text { Turbidity } \\
(\mathrm{NTU})\end{array}$ & $\begin{array}{c}\text { Predicted } \\
\text { Turbidity (Y) } \\
(\mathrm{NTU})\end{array}$ \\
\hline 1 & 6 & 50 & 25 & 10.80 & 10.2913 \\
2 & 7.5 & 250 & 10 & 1.19 & 2.1012 \\
3 & 6 & 250 & 25 & 2.10 & 1.5712 \\
4 & 9 & 250 & 25 & 2.12 & 2.6288 \\
5 & 7.5 & 150 & 25 & 5.31 & 3.6300 \\
6 & 9 & 50 & 25 & 5.46 & 5.9888 \\
7 & 7.5 & 150 & 25 & 4.60 & 3.6300 \\
8 & 9 & 150 & 10 & 1.93 & 0.5100 \\
9 & 6 & 150 & 10 & 1.11 & 2.7275 \\
10 & 9 & 150 & 40 & 1.17 & 1.5525 \\
11 & 7.5 & 50 & 40 & 9.50 & 8.5887 \\
12 & 7.5 & 150 & 25 & 3.13 & 3.6300 \\
13 & 6 & 150 & 40 & 1.16 & 2.5800 \\
14 & 7.5 & 250 & 40 & 1.44 & 0.5487 \\
15 & 7.5 & 50 & 10 & 2.25 & 6.1413 \\
\hline
\end{tabular}

The models are found to be significant at $84.34 \%$ confidence level by the Ftest as shown in Table 5, with ( $p$ value of regression $\leq 0.05$ ). For optimization of the turbidity removal, it was given an insight into the linear, quadratic and interaction effects of the tested operational conditions as will be discussed later. These analyses were done by means of Fisher's "F" test. The "F" test was used to determine the significance of the regression coefficients of the parameters. The p-value is used as a tool to check the significance of each factor and interaction between them. The larger the magnitude of F-value and correspondingly the smaller the "p > F", the more significant are the corresponding model and the individual coefficient [31]. The statistical analysis in Table 5 shows that the linear (MOS dose) was very significant with $\mathrm{p}$-value $<0.05$. However, the quadratic and interaction effects were not significant. In other words, only the linear effect of the MOS dose was the 
major determining condition that might cause considerable effect on the amount of residual turbidity.

Table 5. Response Surface Regression: Analysis of Variance (ANOVA). $R^{2}=$ $84.34 \%$

\begin{tabular}{lrlllll}
\hline Source & & DF & Adj SS & Adj MS & F-Value & $\begin{array}{l}\text { P- } \\
\text { Value }\end{array}$ \\
\hline Model & & 9 & 115.112 & 12.7902 & 3.83 & 0.077 \\
& Linear & 3 & 64.251 & 21.4171 & 6.42 & 0.036 \\
pH & 1 & 2.520 & 2.5200 & 0.75 & 0.425 \\
Dose & 1 & 55.968 & 55.9682 & 16.77 & 0.009 \\
Time & 1 & 5.763 & 5.7630 & 1.73 & 0.246 \\
Square & 3 & 31.264 & 10.4213 & 3.12 & 0.126 \\
pH*pH & 1 & 2.020 & 2.0196 & 0.60 & 0.472 \\
& Dose*Dose & 1 & 8.451 & 8.4514 & 2.53 & 0.172 \\
& Time*Time & 1 & 18.935 & 18.9354 & 5.67 & 0.063 \\
& 2-Way Interaction & 3 & 19.596 & 6.5321 & 1.96 & 0.239 \\
pH*Dose & 1 & 7.182 & 7.1824 & 2.15 & 0.202 \\
pH*Time & 1 & 0.164 & 0.1640 & 0.05 & 0.833 \\
& Dose*Time & 1 & 12.250 & 12.2500 & 3.67 & 0.114 \\
Error & 5 & 16.692 & 3.3383 & & \\
& Lack-of-Fit & 3 & 14.219 & 4.7397 & 3.83 & 0.214 \\
Pure Error & & & & & \\
\hline
\end{tabular}

For the contour plot shown in (Fig. 11a) of turbidity vs. time and $\mathrm{pH}$ at MOS dose $=150 \mathrm{mg} / \mathrm{L}$, the optimum time and $\mathrm{pH}$ which achieved lowest turbidity were between 10-11 min at $\mathrm{pH}=6$. As the time and $\mathrm{pH}$ increases, the residual turbidity increases, and the coagulation process deteriorates. For contour plot of turbidity vs. time and MOS dose at $\mathrm{pH}=7.5$, it was observed that the lowest turbidity was at dose $>100 \mathrm{mg} / \mathrm{L}$ with time $<13 \mathrm{~min}$ (Fig. 11b). As the MOS doses decrease lower than $100 \mathrm{mg} / \mathrm{L}$ with increasing time, the turbidity increased, and the efficiency dropped. At dose $>170 \mathrm{mg} / \mathrm{L}$ with time $>32$ minutes, the turbidity started to decrease again, and the coagulation process was enhanced. For contour plot of turbidity vs. dose (Fig. 11c), $\mathrm{pH}$ at time $=25 \mathrm{~min}$, the lowest turbidity values at dose $>230 \mathrm{mg} / \mathrm{L}$ with $\mathrm{pH}=6$. As the MOS dose decreased of 230 $\mathrm{mg} / \mathrm{L}$ with increasing $\mathrm{pH}$ of 9 , the residual turbidity increased, and the efficiency negatively affected. 
614

JES, Assiut University, Faculty of Engineering, Vol. 49, No. 5, Sept. 2021, pp. 597 - 619
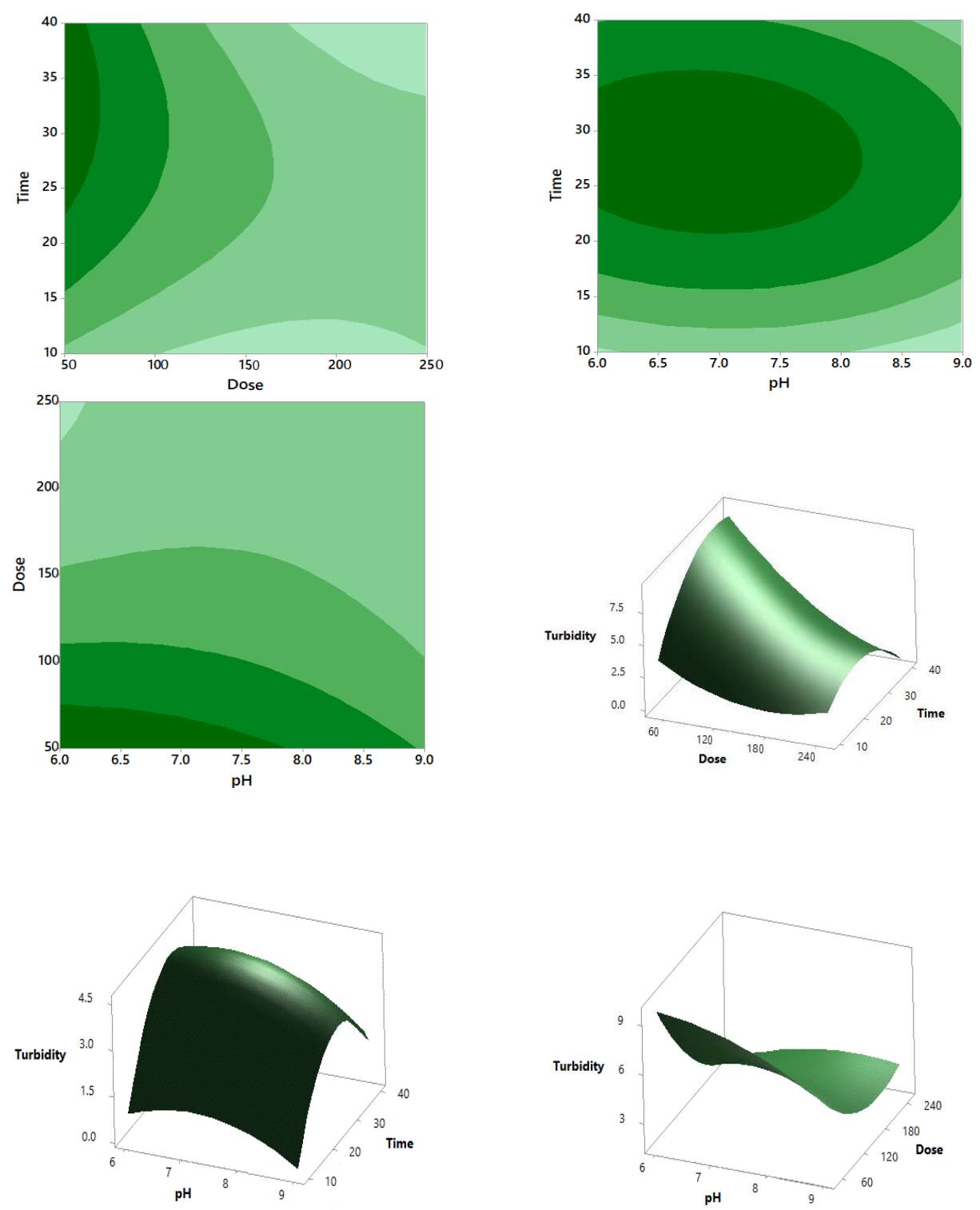

Figure 11.3D surface and 2D contour plots for turbidity using MOS coagulant

Therefore, it was of a prime importance to check the interaction effect between the operational conditions on the response. With employing the optimization tool as shown in Table 6 , if the $\mathrm{pH}$, MOS dose and contact time were adjusted to be respectively $6.15,250 \mathrm{mg} / \mathrm{L}$ and $12.78 \mathrm{~min}$., the turbidity would be 1.0 NTU. Therefore, the resulted turbidity concentration will meet the Egyptian standards for the drinking water. And after applying the check, the residual 
turbidity was found to be $1.04 \mathrm{NTU}$ that was near to meet the Egyptian standards.

For more clarification, Fig. 12 shows the interaction plots between the three investigated operational conditions. For the plots, it was observed that the lowest residual turbidity was achieved at MOS dose, $\mathrm{pH}$, and time around $250 \mathrm{mg} / \mathrm{L}, 6$ and $10 \mathrm{~min}$, respectively. Besides, the more the $\mathrm{pH}$, the higher the turbidity resulted as agreed with Ghebremichael et al. [23] observations since with acidic $\mathrm{pH}$ levels, the hydrophobic links are enhanced [32]. MOS has proteinic and cationic nature that may imply the enhancement of the coagulant activity at low $\mathrm{pH}$ with more MOS dose. Taken overall, it was concluded that the most effective relationship between operational conditions and the coagulation process was the linear MOS dose that achieves $\mathrm{p}<0.05$ and the lowest turbidity value, respectively.

Table 6. The optimum condition for achieving a turbidity target of 1.0 NTU.

\begin{tabular}{llllll}
\hline Solution & $\mathrm{pH}$ & Dose $(\mathrm{mg} / \mathrm{L})$ & Time $(\mathrm{min})$ & Turbidity Fit & $\begin{array}{l}\text { Composite } \\
\text { Desirability }\end{array}$ \\
\hline 1 & 6.15 & 250 & 12.78 & 1 & 1 \\
\hline
\end{tabular}

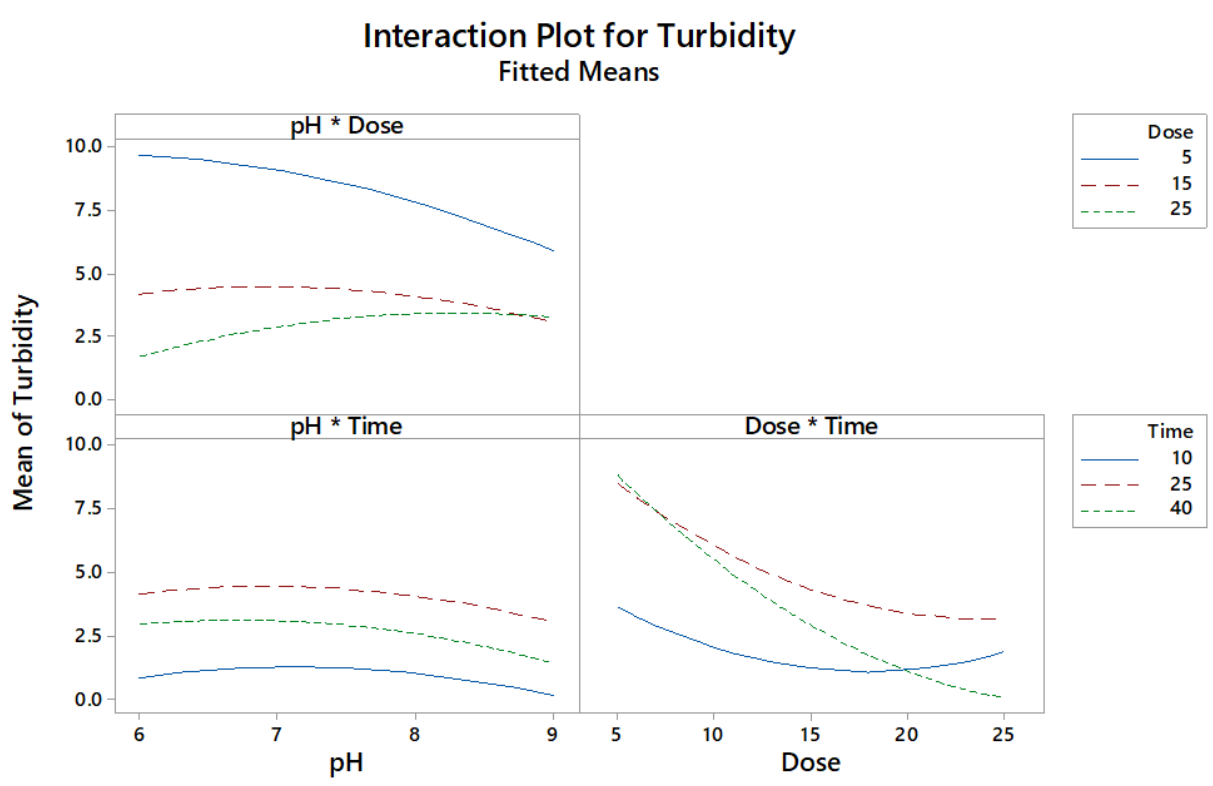

Figure 12. The interaction plots between the factors. 


\section{Conclusions}

MOS coagulant proved a powerful agent for surface water purification where it acts as a purifier of colloids and subsequent charge neutralizer, allowing for effective precipitation out of the solution. Supplementation of sponge to MOS coagulant results in a great effect in enhancing the coagulation process. This mixture improved the turbidity removal from $96 \%$ to $99 \%$ and UV 254 absorbance reduction from $72 \%$ to $93 \%$ at MOS dose of $150 \mathrm{mg} / \mathrm{L}$ and $\mathrm{pH}$ of 7.5. Sponges can be considered an additional filtration step within the coagulation process. RSM using Box Behnken design was applied to evaluate effects of $\mathrm{pH}, \mathrm{MOS}$ dose, and time on the process efficiency, and then determine the optimum conditions. The results showed that only the linear MOS dose played the important role on the removal efficiency of turbidity with $\mathrm{R}^{2}$ of 0.84 and $\mathrm{p}<0.05$. The optimum conditions obtained were at MOS dose, $\mathrm{pH}$, and time of $250 \mathrm{mg} / \mathrm{L}, 6.15$ and 12.78 minutes, respectively to obtain turbidity with a value about 1.0 NTU that is accepted with the Egyptian standards for drinking water.

\section{References}

[1] M.Okuda, A.Baes, W.Nishijima, "Improvement of extraction method of coagulation active components from Moringa Olefiera seed," Elsevier Sci. Ltd, vol. 33, no. 15, pp. 3373-3378, 1999.

[2] A. Ndabigengesere and K. Subba Narasiah, "Quality of water treated by coagulation using Moringa oleifera seeds," Water Res., vol. 32, no. 3, pp. 781$791,1998$.

[3] D.Schultz, "Treating surface waters for communities in develpoing countries," Am.Wat.Wks, no. 75, pp. 212-219, 1983.

[4] S. Kawamura, "Effectiveness of natural polyelectrolytes in water treatment," Wat. Wks. Ass, no. 83, pp. 88-91, 1991.

[5] G.S. Madrona, I.G. Branco, V.J. Seolin, B. de A.A. Filho, M. R. Fagundes-Klen, and R. Bergamasco, "Evaluation of extracts of Moringa oleifera Lam seeds obtained with $\mathrm{NaCl}$ and their effects on water treatment," Acta Sci. - Technol., vol. 34, no. 3, pp. 289-293, 2012.

[6] T. Okuda, A.U. Baes, W. Nishijima, and M. Okada, "Isolation and characterization of coagulant extracted from moringa oleifera seed by salt solution," Water Res., vol. 35, no. 2, pp. 405-410, 2001.

[7] S.A.A.Jahn, "Using Moringa Seeds as coagulants in developing countries," J. Am. Water Works Assoc., vol. 80, no. 6, pp. 43-50, 1988.

[8] J.F.Morton, "The horseradish tree, Moringa pterygosperm (Moringaceae)-a boon to arid lands," Econ.Bot, no. 45, pp. 318-333, 1991.

[9] B. Verdcourt, "A Synopsis of the Moringaceae," Kew Bull., vol. 40, no. 1, pp. 1--ix, 1985. 
[10] S.A.A.Jahn, Proper use of African coagulants for rural water supply: Research in the sudan and guide for new projects. Eschborn, Germany: Deutsche Gesellschaft fur Technische Zusammenarbeit (GTZ), 1986.

[11] S.A.A.Jahn, "studies on natural water coagulants in Sudan, with special reference to Moringa oleifera seeds," Wat.S.A, no. 5, pp. 90-97, 1979.

[12] S.A.A.Jahn, Traditional water purification in developing countries: Existing methods and potential application. Manual 117, Eschborn-Deutsche Gesellschaft fur Technische Zusammenarbeit(GTZ), 1981.

[13] M. Abolore Idris et al., "Moringa Oleifera Seed extract: A review on its environmental applications," Int. J. Appl. Environ. Sci., vol. 11, no. 6, pp. 1469 1486, 2016.

[14] B.Y. Gao, Q.Y. Yue, and Y. Wang, "Coagulation performance of polyaluminum silicate chloride (PASiC) for water and wastewater treatment," Sep. Purif. Technol., vol. 56, no. 2, pp. 225-230, 2007.

[15] J. Beltrán-Heredia, J. Sánchez-Martín, A. Delgado-Regalado, and C. JuradoBustos, "Removal of Alizarin Violet 3R (anthraquinonic dye) from aqueous solutions by natural coagulants.," J. Hazard. Mater., vol. 170, no. 1, pp. 43-50, Oct. 2009.

[16] A. Farghaly, A. Ahmed, A. Gad, and M. Hashem, "A study for producing drinking water with safe trihalomethane concentrations," Clean Technol. Environ. Policy, Sep. 2013.

[17] R.B. Bongiovani, F.P. Camacho, L. Nishi, P.F. Coldebella, K.C. Valverde, A. Vieira, "Improvement of the coagulation/flocculation process using a combination of Moringa oleifera Lam with anionic polymer in water treatment," Environ. Technol., vol. 35, no. 17, pp. 2227-2236, 2014.

[18] A.A. Baptista et al., "Coagulation-flocculation process with ultrafiltered saline extract of Moringa oleifera for the treatment of surface water," Chem. Eng. J., vol. 276, pp. 166-173, 2015.

[19] S.M. Abdulkarim, K. Long, O.M. Lai, S.S. Muhammad, and H.Ghazali, "Some physico-chemical properties of Moringa oleifera seed oil extracted using solvent and aqueous enzymatic methods," Food Chem., vol. 93, no. 2, pp. 253-263, 2005.

[20] A.S. García-Fayos, J.M.Arnal, G.Verdú, "Study of Moringa oleifera oil extraction and its influence in primary coagulant activity for drinking water treatment," in International conference on food innovation; Valencia, 2010, pp. $1-5$.

[21] M.R. Gidde, A.R. Bhalerao, and C.N. Malusare, "Comparative study of different forms of Moringa Oleifera extracts for turbidity removal," Int. J. Eng. Res. Dev., vol. 2, no. 1, pp. 14-21, 2012.

[22] M.M. Sapana, C.G. Sonal, and R.D. , "Use of Moringa Oleifera (Drumstick) seed as natural absorbent and an antimicrobial agent for ground water treatment," Res. J. Recent Sci. Res.J.Recent Sci, vol. 1, no. 3, pp. 31-40, 2012.

[23] K.A. Ghebremichael, K.R. Gunaratna, and G. Dalhammar, "Single-step ion exchange purification of the coagulant protein from Moringa oleifera seed.," Appl. Microbiol. Biotechnol., vol. 70, no. 5, pp. 526-532, May 2006. 
[24] M. Tandukar, S. Uemura, I. Machdar, A. Ohashi, and H. Harada, "A low-cost municipal sewage treatment system with a combination of UASB and the 'fourth-generation' downflow hanging sponge reactors," Water Sci. Technol., vol. 52, no. 1-2, pp. 323-329, 2005.

[25] K. Kubota et al., "Microbial community composition of a down-flow hanging sponge (DHS) reactor combined with an up-flow anaerobic sludge blanket (UASB) reactor for the treatment of municipal sewage," Bioresour. Technol., vol. 151, pp. 144-150, 2013, doi: 10.1016/j.biortech.2013.10.058.

[26] J. Sánchez-Martín, K. Ghebremichael, and J. Beltrán-Heredia, "Comparison of single-step and two-step purified coagulants from Moringa oleifera seed for turbidity and DOC removal," Bioresour. Technol., vol. 101, no. 15, pp. 62596261, 2010.

[27] M.S.B. Garcia-Fayos, J.M. Arnal and To, "Moringa Oleifera for drinking water treatment: influence of the solvent and method used in oil- extraction on the coagulant efficiency of the seed extract,” Desalin. Water Treat., pp. 1944-3994, 2015.

[28] G.S. Madrona, G.B. Serpelloni, A.M. Salcedo Vieira, L. Nishi, K.C. Cardoso, and R. Bergamasco, "Study of the effect of saline solution on the extraction of the Moringa Oleifera seed's active component for water treatment," Water. Air. Soil Pollut., vol. 211, no. 1-4, pp. 409-415, 2010.

[29] M.O.T.Okuda, A.U.Baes, W.Nishijima, "Coagulation mechanism of salt solution-extracted active in Moringa Olefiera seeds," Elsevier Sci. Ltd, vol. 35, no. 3, pp. 830-834, 2001.

[30] J. Khuri, Response Surfaces: Designs and Analyses, 2nd Edition. New York, 1996.

[31] H. Rushing,A. Karl,J. Wisnowski,"Design and analysis of experiments by Douglas Montgomery: A supplement for using JMP(R)," SAS Institute Inc., Cary, North Carolina, USA, 2013.

[32] S. Katayon et al., "Effects of storage conditions of Moringa oleifera seeds on its performance in coagulation," Bioresour. Technol., vol. 97, no. 13, pp. 14551460, 2006. 


\section{دراسة معملية لاستخدام المورينجا كمادة مروبة طبيعية في تنقية مياه الثرب}

الملخص

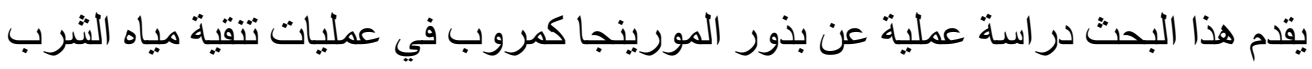

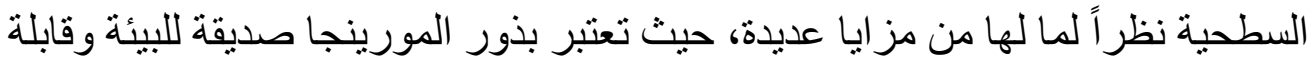

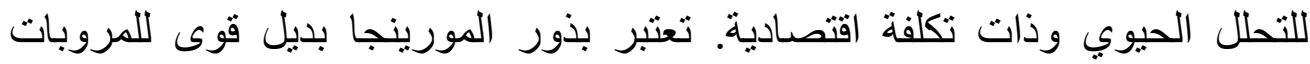

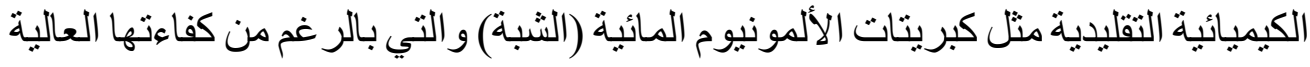

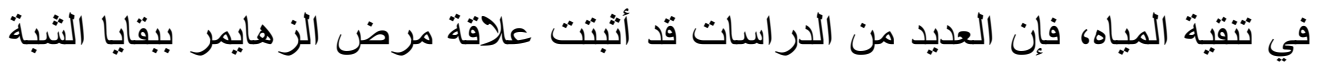

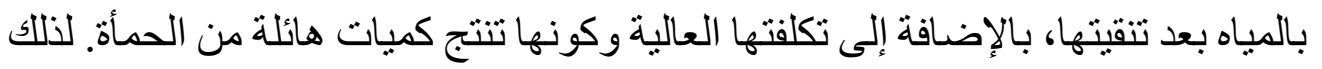
كان من الضروري البحث عن مروبات طبيعية بديلة لمعالجة المياه السطحية وبحيث تتلافى العيوب السابقة من الفروب البحن

تم في هذا البحث رفع كفاءة استخدام بذور المورينجا كمروب بإضافة واستخدام الإسفنج

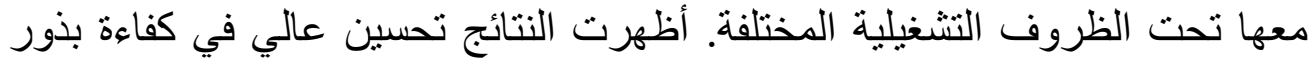
المورينجا كمروب في تنقية المياه السطحية دون وجود انسداد ملحوظ في مسامات

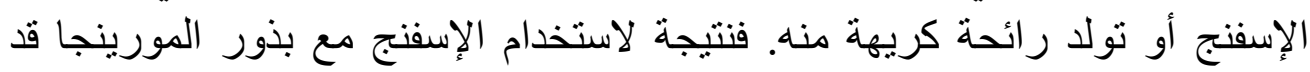

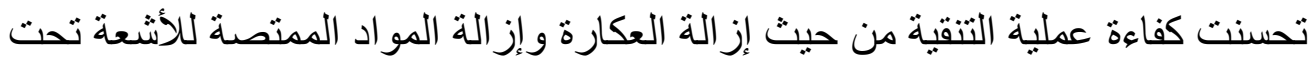

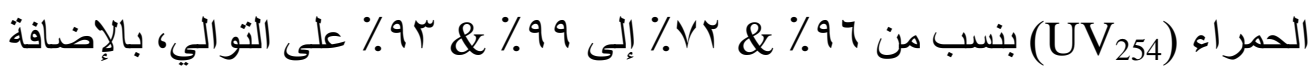

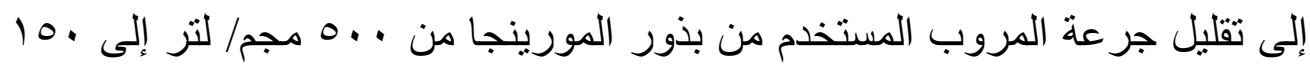

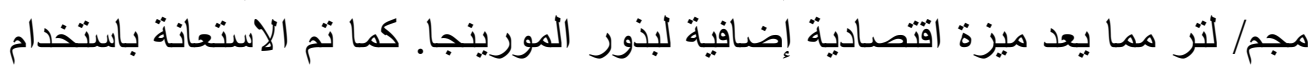

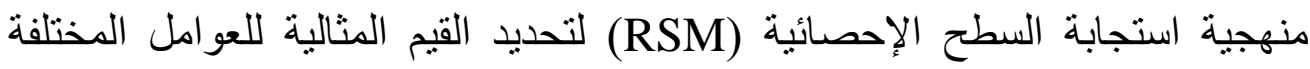

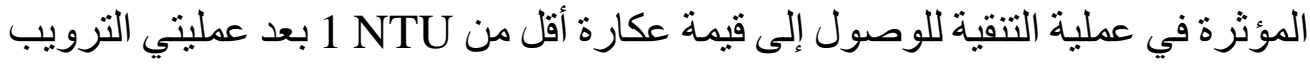
و الترسيب بدون أي عمليات ترشيح للمياه وكانت النتائج تتلخص في في أن عملية التنقية

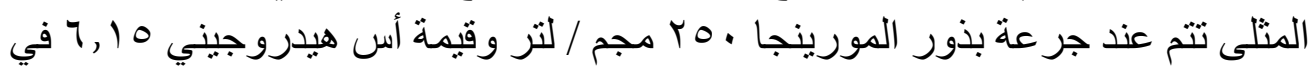

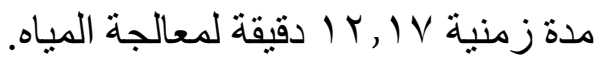

